\title{
Linear Regression Analysis on Factors Affecting Health Surveillance Personnel Performance in Early Detection of Preeclampsia in Semarang, Central Java
}

\author{
Zella Cahyandaru1), Didik Tamtomo'), RB Soemanto3) \\ ${ }^{1)}$ Masters Program in Public Health, Universitas Sebelas Maret \\ ${ }^{2}$ )Faculty of Medicine, Universitas Sebelas Maret \\ 3)Faculty of Social and Political Sciences, Universitas Sebelas Maret
}

\begin{abstract}
Background: Preeclampsia is a major cause of maternal death both globally and regionally. It can be prevented either through continuous surveillance and early detection activities. City Health Office in Semarang recruited health surveillance officers as an effort to reduce maternal mortality especially due to preeclampsia. The purpose of this study was to analyze factors associated with health surveillance personnel performance in the early detection of preeclampsia.

Subjects and Method: This was an analytic observational study with a cross sectional design. The study was conducted in 26 community health centers in Semarang, from October to December 2018. A sample 148 health surveillance personnels was selected by exhaustive sampling. The dependent variable was health surveillance personnels performance. The independent variables were age, work motivation, work stress, job satisfaction, leadership style, and supervision. The data were collected by questionnaire and analyzed by a multiple linear regression.

Results: Health surveillance personnel's performance in early detection of preeclampsia was positively associated with strong work motivation $(b=0.12 ; 95 \% \mathrm{CI}=0.07$ to $0.16 ; \mathrm{p}<0.001)$, low work stress $(b=0.08 ; 95 \% C I=-0.01$ to $0.15 ; p=0.058)$, work satisfaction $(b=0.10 ; 95 \% C I=0.05$ to $0.15 ; \mathrm{p}<0.001)$, leadership style $(\mathrm{b}=0.23 ; 95 \% \mathrm{CI}=0.10$ to $0.37 ; \mathrm{p}=0.001)$, and good supervision $(b=0.31 ; 95 \% \quad C I=0.18$ to $0.45 ; \mathrm{p}<0.001)$. Health surveillance personnel's performance was negatively associated with older age $(b=-0.08 ; 95 \% \mathrm{CI}=-0.16$ to $0.01 ; \mathrm{p}=0.050)$.

Conclusions: Health surveillance personnel performance in early detection of preeclampsia is positively associated with strong work motivation, low work stress, work satisfaction, leadership style, and good supervision. Performance is negatively associated with older age.
\end{abstract}

Keywords: early detection, preeclampsia, performance, health surveillance personnel

\section{Correspondence:}

Zella Cahyandaru. Masters Program in Public Health, Universitas Sebelas Maret. Jl. Ir. Sutami 36A, Surakarta, Central Java 57126, Indonesia. Email: zellacahyandaru@gmail.com.

Mobile: +6287832622469 .

\section{BACKGROUND}

Preeclampsia is one of the direct causes of maternal mortality, especially in low and middle income countries (Say et al., 2014; Pasha et al., 2018; Saleem et al., 2014). Preeclampsia is a specific syndrome that occurs after 20 weeks' gestation characterized by the presence of hypertension, proteinuria, and other maternal organ dysfunctions (Bro Schmidt et al., 2017; Jeyabalan, 2013; Mol et al., 2016). If preeclamp- sia is not treated properly, it can lead to complications in both the mother and fetus (Bokslag et al., 2016; Jim and Karumanchi, 2017).

Globally, the prevalence of preeclampsia reaches $0.2-9.2 \%$ and causes 76,000 maternal deaths annually (Umesawa and Kobashi, 2016; USAID, 2017). In Indonesia, the causes of maternal deaths due to hypertension in pregnancy including preeclampsia continued to increase, from $21.5 \%$ in 
2010 to $27.1 \%$ in 2013 (Pusdatin Ministry of Health, 2014).

Hypertension in pregnancy is the first cause of maternal death in Central Java in 2017 with a percentage of $32.97 \%$. Semarang was in the fourth place with 23 cases of maternal deaths in which the highest obstetric causes of maternal mortality were caused by preeclampsia / eclampsia, which amounted to $21.74 \%$ (Central Java Health Office, 2018; Semarang City Health Office, 2018).

Before complications from preeclampsia occur, prevention can be done, one of them is continuous surveillance and early detection, which is the main support of the management of preeclampsia. The implementation of early detection of appropriate preeclampsia can produce great benefits for both the mother and the fetus (Von Dadelszen and Magee, 2016; Mol et al., 2016; Domingo et al., 2017).

One of the efforts made by the Semarang City Health Office in order to reduce cases of maternal mortality, especially as a result of preeclampsia, is to recruit surveillance officers for maternal and child health. The main tasks of health surveillance officers include data collection and assistance for pregnant women both normal and high risk, including the early detection of preeclampsia (Semarang City Health Office, 2017; Semarang City Health Office 2018).

Human resources are one of the factors that influence health services. Through good quality human resources can increase the coverage of existing health services. One of the qualities of human resources can be measured through performance (Mosadeghrad, 2014; WHO, 2015; Scheffler et al., 2016). Data from the Semarang City Health Office (2018) on data collection for 2017 pregnant women including the early detection of preeclampsia shows that the implementation has not been optimal, as evidenced by the presence of health surveillance officers who have not reached the set targets.

Performance can be influenced by individual characteristics, such as job satisfaction, work stress, and work motivation. Individual characteristics are important because they can influence the way a person behaves in the workplace. In addition to individual characteristics, a leader's leadership style can also influence a person's performance so that he can achieve established organizational goals (Colquitt et al., 2011). In addition to these factors, a person's performance can also be influenced by age and supervision from superiors (Bertolino et al., 2013; Madede et al., 2017).

The purpose of this study was to analyze factors associated with performance of health surveillance personnel in the early detection of preeclampsia.

\section{SUBJECTS AND METHOD \\ 1. Study design \\ This was an analytic observational study with a cross sectional design. The study was conducted in 26 Semarang health centers, from October to December 2018.}

\section{Population and sample}

The target population of this study was health surveillance officers. The source population of this study was the maternal and child health surveillance personnels in 26 Semarang community health centers. A sample 148 health surveillance personnels was selected by exhaustive sampling.

\section{Study variables}

The dependent variable was health surveillance personnels performance. The independent variables were work motivation, work stress, job satisfaction, age, leadership style, and supervision. 


\section{Operational definition of variables}

Surveillance personnel's performance in the early detection of preeclampsia was defined as work achievement in conducting early detection of preeclampsia in accordance with their authority and responsibility in achieving the goals set by the Semarang Health Office. The measurement scale was continuous and transformed into dichotomous, coded o for poor (score <13) and 1 for good (score $\geq 13$ ).

Work motivation was defined as a desire from within a health surveillance officer that can generate enthusiasm or encouragement in work especially in the early detection of preeclampsia. The measurement scale was continuous and transformed into dichotomous, coded o for low (score <22) and 1 for high (score $\geq 22$ ).

Stress because of job was defined as a psychological response to demands that exceed the capacity or resources of the health surveillance officer both physically and psychologically. The measurement scale was continuous and transformed into dichotomous, coded o for high (score <15) and 1 for low (score $\geq 15$ ).

Job satisfaction was defined as a positive feeling produced by a health surveillance officer from an assessment or experience regarding various job characteristics. The measurement scale continuous and transformed into dichotomous, coded o for low (score <21) and 1 for high (score $\geq 21$ ).

Age was defined as the length of life of a health surveillance officer from birth. The measurement scale was continuous and transformed into dichotomous, coded o for $<25$ years and 1 for $\geq 25$ years.

Leadership style was defined as the result of the interpretation of the behavior patterns shown by the coordinating midwife in influencing the health surveillance officer to achieve the goal. The measure- ment scale was continuous and transformed into dichotomous, coded o for transactional leadership style (score $<6$ ) and 1 for transformational leadership style (score $\geq 6$ ).

Supervision of coordinator midwives was defined as the process of coordinating midwives in periodically directing and supporting health surveillance officers so that work can be carried out effectively. The measurement scale was continuous and transformed into dichotomous, coded o for weak supervision (score <7) and 1 for strong supervision (score $\geq 7$ ).

\section{Study instrument}

The data were collected by questionnaire. The validity test was done with content validity and face validity. The reliability testing in this study was conducted on 20 maternal and child health surveillance personnels by calculating total item correlation ( $\geq 0.20)$ and Cronbach's alpha $(\geq 0.70)$.

\section{Data Analysis}

Univariate analysis was described in frequency and percentage. Bivariate analysis was performed by Pearson correlation test. Multivariate analysis was conducted by a multiple linear regression to examine the effects of work motivation, work stress, job satisfaction, age, leadership style, and supervision on health surveillance personnel's performance in early detection of preeclampsia.

\section{Research Ethics}

The research ethics including informed consent, anonymity, confidentiality), and ethical clearance. The ethical clearance was obtained from Research Ethics Committee, Universitas Sebelas Maret, Surakarta, Central Java, with number: 296/ UN27.6/ KEPK/ 2018. 
Journal of Health Policy and Management (2019), 4(1): 13-22

https://doi.org/10.26911/thejhpm.2019.04.01.02

\begin{tabular}{|c|c|c|}
\hline \multicolumn{3}{|c|}{ RESULTS } \\
\hline \multicolumn{3}{|l|}{ 1. Univariate Analysis } \\
\hline Characteristics & $\mathbf{n}$ & $\%$ \\
\hline \multicolumn{3}{|l|}{ Marital Status } \\
\hline Married & 45 & 30.4 \\
\hline Single & 103 & 69.6 \\
\hline \multicolumn{3}{|l|}{ Tenure } \\
\hline$<2$ years & 73 & $49 \cdot 3$ \\
\hline $\begin{array}{l}\geq 2 \text { years } \\
\text { The distance from } \\
\text { residence }\end{array}$ & 75 & 50.7 \\
\hline$<5 \mathrm{~km}$ & 79 & 53.4 \\
\hline$\geq 5 \mathrm{~km}$ & 69 & 46.6 \\
\hline \multicolumn{3}{|l|}{ Working motivation } \\
\hline Low & 72 & 48.6 \\
\hline High & 76 & 51.4 \\
\hline \multicolumn{3}{|l|}{ Work stress } \\
\hline Low & 94 & 63.5 \\
\hline High & 54 & 36.5 \\
\hline \multicolumn{3}{|l|}{ Working Satisfaction } \\
\hline Low & 60 & 40.5 \\
\hline High & 88 & 59.5 \\
\hline \multicolumn{3}{|l|}{ Age } \\
\hline$<25$ years & 73 & 49.3 \\
\hline $\begin{array}{l}\geq 25 \text { years } \\
\text { Leadership style }\end{array}$ & 75 & 50.7 \\
\hline Transactional & 97 & $65 \cdot 5$ \\
\hline Transformational & 51 & 34.5 \\
\hline \multicolumn{3}{|l|}{ Supervision } \\
\hline Not Intens & 64 & 43.2 \\
\hline Intens & 84 & 56.8 \\
\hline \multicolumn{3}{|l|}{ Performance } \\
\hline Low & 39 & 26.4 \\
\hline High & 109 & 73.6 \\
\hline
\end{tabular}

Table 1 showed sample characteristics. Table 1 showed that most of sample were single (69.6\%), tenure $\geq 2$ years (50.7\%), and the distance from home to workplace $<5 \mathrm{~km}(53.4 \%)$.

As many as $51.4 \%$ sample had high motivation, low work stress (63.5\%), high job satisfaction (59.5\%), age $\geq 25$ years (50.7\%), transactional leadership style (65.5\%), intense supervision (56.8\%), and high performance (73.6\%).

\section{Bivariate Analysis}

Table 2. The result of bivariate analysis

\begin{tabular}{lcc}
\hline $\begin{array}{c}\text { Independent } \\
\text { Variables }\end{array}$ & $\mathbf{r}$ & $\mathbf{p}$ \\
\hline Work Motivation & 0.51 & $<0.001$ \\
Work Stress & -0.03 & 0.678 \\
Job Satisfaction & 0.37 & $<0.001$ \\
Age & -0.16 & 0.060 \\
Supervision & 0.31 & $<0.001$ \\
Leadership & 0.44 & $<0.001$ \\
\hline
\end{tabular}

Table 2 showed the result of bivariate analysis. Table 2 showed that health surveillance personnel's was positively associated with work motivation $(\mathrm{r}=0.51 ; \mathrm{p}$ $<0.001)$, job satisfaction $(\mathrm{r}=0.37$; $\mathrm{p}$ $<0.001)$, leadership style $(\mathrm{r}=0.31 ; \mathrm{p}$ $<0.001)$, and supervision ( $\mathrm{r}=0.44 ; \mathrm{p}$ $<0.001)$. Health surveillance personnel's performance was negatively associated with age $(\mathrm{r}=-0.16 ; \mathrm{p}=0.060)$.

\section{Multivariate Analysis}

Table 3 showed the results of a multiple linear regression analysis. Table 3 showed that health surveillance personnel's performance was positively associated with work motivation, work stress, job satisfaction, leadership style, and supervision. Health surveillance personnel's performance was negatively associated with age.

There was a positive effect of work motivation on the performance of health surveillance personnels in early detection of preeclampsia. An increase of work motivation would increase the performance of the health surveillance personnels by 0.12 units $(b=0.12 ; 95 \% \mathrm{CI}=0.07$ to $0.16 ; \mathrm{p}<0.001)$.

There was a positive effect of work stress on the performance of health surveillance personnels in early detection of preeclampsia. An increase of work stress would increase the performance of the health surveillance personnels by 0.08 units $(b=0.08 ; 95 \% \mathrm{CI}=-0.01$ to $0.15 ; \mathrm{p}=$ o.058). 
There was a positive effect of job satisfaction on the performance of health surveillance personnels in early detection of preeclampsia. An increase of job satisfaction would increase the performance of the health surveillance personnels by 0.10 units ( $b=0.10 ; 95 \% \mathrm{CI}=0.05$ to $0.15 ; \mathrm{p}<0.001$ ).

There was a negative effect of age on the performance of health surveillance personnels in early detection of preeclampsia. An increase of age would decrease the performance of health surveillance personnels by 0.08 units $(b=-0.08 ; 95 \% \mathrm{CI}=-0.16$ to $0.01 ; \mathrm{p}=0.050$ ).
There was an effect of leadership style on the performance of health surveillance personnels in early detection of preeclampsia. An increase of leadership style would increase the performance of health surveillance personnels by 0.23 units $(b=0.23$; 95\% $\mathrm{CI}=0.10$ to $0.37 ; \mathrm{p}=0.001$ ).

There was a positive effect of supervision on the performance of health surveillance personnels in early detection of preeclampsia. An increase of supervision would increase the performance of health surveillance personnels by 0.31 units $(b=$ $0.31 ; 95 \% \mathrm{CI}=0.18$ to $0.45 ; \mathrm{p}<0.001)$.

Table 3. The results of a multiple linear regression

\begin{tabular}{|c|c|c|c|c|}
\hline \multirow{2}{*}{ Variables } & \multirow{2}{*}{$\mathbf{b}$} & \multicolumn{2}{|c|}{ 95\% CI } & \multirow[b]{2}{*}{$\mathbf{p}$} \\
\hline & & Lower & Upper & \\
\hline Work Motivation & 0.12 & 0.07 & 0.16 & $<0.001$ \\
\hline Work Stress & 0.08 & -0.01 & 0.15 & 0.058 \\
\hline Job Satisfaction & 0.10 & 0.05 & 0.15 & $<0.001$ \\
\hline Age & -0.08 & -0.16 & 0.01 & 0.050 \\
\hline Perceptions of the leadership style of coordinating & 0.23 & 0.10 & 0.37 & 0.001 \\
\hline midwife & 0.31 & 0.18 & 0.45 & $<0.001$ \\
\hline
\end{tabular}

Supervision of coordinating midwife

$\mathrm{N}$ observed $=148$

Adjusted R Square $=0.45$

\section{DISCUSSION \\ 1. The effect of work motivation on the performance of health surveil- lance personnels}

The result of this study showed that there was a positive effect of work motivation on the performance of health surveillance personnels in early detection of preeclampsia. The result of this study was in line with previous studies which stated that there was an effect of work motivation on the performance of employees in doing their job (Kok et al., 2015; Yousaf et al., 2015).

Adjei et al. (2016) mentioned that work motivation affected the performance. Employees who have motivation can be physiologically stable, psychologically balanced and perform their duties effectively with the attention needed, so as to improve their performance.

The ability of the health system to provide quality health services depend on the availability of motivated health personnels. The motivation of the work of health personnel was the key to the accessibility of good health services, especially for rural communities, where most of the indicators were still lacking (WHO, 2014; Mutale et al., 2013).

\section{The effect of work stress on the performance of health surveillance personnels}

The result of this study showed that there was a positive effect of work stress on the performance of health surveillance personnels in the early detection of preeclampsia. 
The result of this study was in line with a study by Ahmad et al. (2018) which stated that there was a relationship between work stress and the performance.

A study by Zafar et al. (2015) stated that stress on employees can improve the performance. Stress related to work can have a positive or negative impact on employee's performance. Eustress (positive stress) was needed to improve employee's performance. Certain levels of stress possessed by employees could improve their efficiency and effectiveness. Conversely, if the stress level was too high, it could have a negative impact on employee's performance such as a decrease in productivity and worsen the quality of work.

\section{The effect of job satisfaction on the performance of health surveillance personnels}

The result of this study showed that there was a positive effect of job satisfaction on the performance of health surveillance personnels in the early detection of preeclampsia. The result of this study was in line with a study by Bowling et al. (2013) which stated that there was a relationship between job satisfaction and the performance which was statistically significant.

Job satisfaction was an important determinant associated with the quality of life of health personnels. Quality of life related to health mean that health personnels with job satisfaction would have better physical and mental health. In addition, job satisfaction could also affect the performance and productivity so that it influenced the health services provided to the clients. Therefore, it was important for health service managers to increase the work satisfaction of health personnels (Ioannou et al., 2015; Faragher et al., 2013; Nadinloyi et al., 2013; Li et al. 2014).

\section{The effect of age on the perform- ance of health surveillance per- sonnels}

The result of this study showed that there was a negative effect of age on the performance of health surveillance personnels in the early detection of preeclampsia.

The result of this study was in line with a study by Letvak et al. (2013) which stated that there were significant differences between young nurses and old nurses in health related to productivity. This study showed that older nurses were often associated with health problems than younger nurses, and these health problems lead to a decrease in productivity and performance. Older nurses have higher pain levels, higher body mass index, and more health problems. In addition, according to Beratha et al. (2013), age factors could affect someone's physical and psychological strength, because at a certain age, an employee would experience changes in work potential.

\section{The effect of perception of the leadership style of coordinating midwife on the performance of health surveillance personnels}

The result of this study showed that there was an effect of leadership style on the performance of health surveillance personnels in the early detection of preeclampsia.

The result of this study was in accordance with a study by Schwarz (2017) which stated that leadership style, especially transformational style has a positive effect on employee's performance. In this study, it showed that the level of higher transformational leadership behavior could improve employee's performance. The results of this study were also in line with a study by Breevaart et al. (2015) which explained that transformational leadership was positively related to employee's performance $(b=0.11$; $95 \% \mathrm{CI}=0.03$ to $0.19 ; \mathrm{p}<0.05$ ). 
Through the components of transformational leadership style that were shown by leaders to employees (idealized influences; inspirational motivation; intellectual stimulation; and individual consideration) were able to cause psychological health so that it increased the employee's performance (Olu-Abiodun and Abiodun, 2017; Wang et al., 2011; Lin et al., 2015).

\section{The effect of supervision on health surveillance personnel perform- ance}

There was a positive effect of supervision on the performance of health surveillance personnels in the early detection of preeclampsia. The result of this study was in accordance with a study by Doloh et al. (2018) which stated that there was an effect of supervision on employee's performance. Nurses with good supervision were 0.97 times more likely to have good performance than nurses with less supervision.

Quality support and supervision in the health system were needed to improve the performance of health personnels and service effectiveness (Chipukuma et al., 2018; Snowdon et al., 2017). Kok et al. (2017) stated that health personnels needed to feel empowered and got supports through the environment, one of them was supervision. The empirical research showed that many health personnels felt that they were not supported by the parties above, so that it could hamper their motivation and performance. Bosch-Capblanch et al. (2011) recommended that the implementation of higher levels of supervision in the health care system could be applied widely, especially in low and middle income countries.

From the description above, it can be concluded that work motivation, work stress, job satisfaction, leadership style, and supervision associated with performance of health surveillance personnels in the early detection of preeclampsia.

\section{REFERENCES}

Adjei KA, Emmanuel O, Forster $\mathrm{O} \quad \mathrm{M}$ (2016). The Impact of Motivation on the Work Performance of Health Workers (Korle Bu Teaching Hospital): Evidence from Ghana. Hospital Practices and Research Journal, 1(2): 45. doi: 10.20286/hpr-010245.

Ahmad EH, Maidin A, Abdullah T, Naiem F, Buraerah S, Handayanif R, Prihantono P (2018). Relationship of work stress to the performance of intensive care unit nurses in Makassar. American Journal of Public Health Research, 6(1): 18. doi: 10.12691/ajphr-61-4.

Beratha O, Wirakusuma IB, Sudibya A (2013).Hubungan karakteristik, motivasi, dan dana BOK dengan kinerja petugas KIA Puskesmas di Kabupaten Gianyar. Public Health and Preventive Medicine Archive, 1(1): 4.

Bertolino M, Truxillo D, Fraccaroli F (2013). Age effects on perceived personality and job performance. Journal of Managerial Psychology, 28(7/8): 878. doi:10.1108/jmp-07-2013-0222.

Bokslag A, van Weissenbruch M, Mol BW, de Groot CJM (2016). Preeclampsia; short and long-term consequences for mother and neonate. Early Human Development, 102: 47-50. doi: 10.1016/j.earlhumdev.2016.09.007.

Bosch-Capblanch X, Liaqat S, Garner P (2011). Managerial supervision to improve primary health care in low- and middle-income countries. Cochrane Database of Systematic Reviews. doi: 10.1002/14651858.cdoo6413.pub2.

Bowling NA, Khazon S, Meyer RD, Burrus CJ (2013). Situational Strength as a Moderator of the Relationship between Job Satisfaction and Job Per- 
Journal of Health Policy and Management (2019), 4(1): 13-22

https://doi.org/10.26911/thejhpm.2019.04.01.02

formance: A Meta-Analytic Examination. Journal of Business and Psychology, 30(1): 93. doi:10.1007/s10869013-9340-7.

Breevaart K, Bakker AB, Demerouti E, Derks D (2015). Who takes the Lead? A multi-source diary study on leadership, work engagement, and job performance. Journal of Organizational Behavior, 37(3): 317. doi: 10.1002/job.2041

Bro Schmidt G, Christensen M, Breth Knudsen U (2017). Preeclampsia and Later Cardiovascular Disease - What do National Guidelines Recommend?. Pregnancy Hypertension, 10: 5. doi: 10.1016/j.preghy.2017.07.139.

Chipukuma HM, Zulu JM, Jacobs C, Chongwe G, Chola M, Halwiindi H, Zgambo J, Michelo C (2018). Towards a framework for analyzing determinants of performance of community health workers in malaria prevention and control: A systematic review. Human Resources for Health, 16(1), p: 11. doi:10.1186/s12960-018-0284-x Colquitt JA, Lepine JA, Wesson MJ (2011). Organizational behavior: improving performance and comitment in the workplace. New York: The McGrawHill Companies, Inc: 10-505

Dinas Kesehatan Provinsi Jawa Tengah (2018). Buku Saku Kesehatan tahun 2017. http://dinkesjatengprov.go.id/v2018/dokumen/bukusaku_2017/mo bile/index.html\#p=25 - Diakses 10 Mei 2018.

Dinas Kesehatan Kota Semarang (2018). Profil Kesehatan Kota Semarang 2017. Semarang: Dinkes Kota Semarang (2018). Petugas surveilans kesehatan ibu dan anak (Gasurkes KIA) tahun 2017. Semarang: Dinkes Kota Semarang
(2017). Profil kesehatan Kota Semarang 2016. https://kupdf.com/download/profil-kesehatan-kota-semarang-2016pdf_59eafiefo8bbc58508e65d65_pdf Diakses 15 Februari 2018

Doloh N, Tamtomo D, Sulaeman ES (2018). Factors Affecting Work Performance among Nurses in Delivering Health Service for the National Health Insurance Patients at Dr. Moewardi Hospital, Surakarta. Journal of Health Policy and Management (2018), 3(1): 22-4. doi: https://doi.org/10.26911/thejhpm.2018.03.01.03.

Domingo KB, Grossman DC, Curry SJ, Barry MJ, Davidson KW, Doubeni CA, Epling JW, et al (2017). Screening for preeclampsia US preventive services task force recommendation statement. Journal of the American Medical Association. 317(16): 1661. doi: 10.1001/jama.2017.3439

Faragher EB, Cass M, Cooper CL (2013). The relationship between job satisfaction and health: A meta-analysis. from stress to wellbeing. 1: 269. doi: 10.1057/9781137310651_12.

Ioannou P, Katsikavali V, Galanis P, Velonakis E, Papadatou D, Sourtzi P (2015). Impact of job satisfaction on greek nurses' health-related quality of life. Safety and Health at Work, 6(4): 327. doi: 10.1016/j.shaw.2015.07.010.

Jeyabalan A (2013). Epidemiology of preeclampsia: impact of obesity. Nutrition Reviews, 71: S18-S25. doi: 10.1111/nure.12055.

Jim B, Karumanchi SA (2017). Preeclampsia: pathogenesis, prevention, and long-term complications. Seminars in Nephrology, 37(4): 388-394. doi: 10.1016/j.semnephrol.2017.05.011

Kok MC, Broerse JEW, Theobald S, Ormel H, Dieleman M, Taegtmeyer M 
(2017). Performance of community health workers: situating their intermediary position within complex adaptive health systems. Human Resources for Health, 15(1): 5. doi: 10.1186/s12960-017-0234-z.

Kok MC, Kane SS, Tulloch O, Ormel H, Theobald S, Dieleman M, Taegtmeyer $\mathrm{M}$, et al. (2015). How does context influence performance of community health workers in low- and middleincome countries? Evidence from the Literature. Health Research Policy and Systems, 13(1): 9. doi: 10.1186/s12961-015-0001-3.

Letvak S, Ruhm C, Gupta S (2013). Differences in health, productivity and quality of care in younger and older nurses. Journal of Nursing Management, 21(7): 918-9. doi: 10.1111/jonm.12181.

Li L, Hu H, Zhou H, He C, Fan L, Liu X, Zhang Z, et al. (2014). Work stress, work motivation and their effects on job satisfaction in community health workers: a cross-sectional survey in China. BMJ Open. 4: 8 doi: 10.1136/bmjopen-2014-004897.

Lin PY, MacLennan S, Hunt N, Cox T (2015). The influences of nursing transformational leadership style on the quality of nurses' working lives in Taiwan: A cross-sectional quantitative study. BMC Nursing, 14(1): 6. doi: 10.1186/s12912-015-0082-x.

Madede T, Sidat M, McAuliffe E, Patricio SR, Uduma O, Galligan M, Bradley S, et al. (2017). The impact of a supportive supervision intervention on health workers in Niassa, Mozambique: a Cluster-Controlled Trial. Human Resources for Health, 15(1): 10. doi:10.1186/s12960-017-0213-4.

Mol BWJ, Roberts CT, Thangaratinam S, Magee LA, de Groot CJM, Hofmeyr
GJ (2016). Pre-eclampsia. The Lancet, 387(10022): 999-1007. doi: 10.1016/s0140-6736(15)00070-7.

Mosadeghrad AM (2014). Factors influencing healthcare service quality. International Journal of Health Policy and Management, 3(2): 81. doi: 10.15171/ijhpm.2014.65.

Mutale W, Ayles H, Bond V, Mwanamwenge MT, Balabanova D (2013). Measuring health workers' motivation in rural health facilities: baseline results from three study districts in Zambia. Human Resources for Health, 11(1): 6. doi:10.1186/1478-4491-11-8.

Nadinloyi KB, Sadeghi H, Hajloo N (2013). Relationship between job satisfaction and employees mental health. Procedia - Social and Behavioral Sciences, 84: 296. doi: 10.1016/j.sbspro.2013.06.554 .

Olu-Abiodun O, Abiodun O (2017). Perception of transformational leadership behaviour among general hospital nurses in Ogun State, Nigeria. International Journal of Africa Nursing Sciences, 6: 25. doi: 10.1016/j.ijans.2017.02.001.

Pasha O, McClure E, Saleem S, Tikmani S, Lokangaka A, Tshefu A, Bose CL, et al. (2018). A prospective cause of death classification system for maternal deaths in low and middle-income countries: Results from the Global Network Maternal Newborn Health Registry. BJOG: An International Journal of Obstetrics \& Gynaecology, 125(9): 1442. doi: 10.1111/1471-0528.15011.

Pusat Data dan Informasi Kementerian Kesehatan RI (2014). Situasi Kesehatan Ibu. http://www.depkes.go.id/resources/download/pusdatin/infoda 
Journal of Health Policy and Management (2019), 4(1): 13-22

https://doi.org/10.26911/thejhpm.2019.04.01.02

tin/infodatin-ibu.pdf - Diakses 14 Februari 2018.

Saleem S, McClure EM, Goudar SS, Patel A, Esamai F, Garces A, Chomba E, et al. (2014). A prospective study of maternal, fetal and neonatal deaths in lowand middle-income countries. Bulletin of the World Health Organization, 92(8): 608. doi:10.2471/blt.13.127464

Say L, Chou D, Gemmill A, Tunçalp Ö, Moller AB, Daniels J, Gülmezoglu AM, et al (2014). Global Causes of Maternal Death: a WHO Systematic Analysis. Lancet Global Health. 2: 328. doi: https://doi.org/10.1016/S2214-109X(14)70227-X.

Scheffler RM, Herbst CH, Lemiere C, Campbell J (2016). Health labor market analyses in low and middleincome countries. Washington DC: the World Bank: 163-5.

Schwarz G (2017). Transformational leadership and job performance: the role of organizational identification. The Palgrave Handbook of Leadership in Transforming Asia: 530. doi: 10.1057/978-1-137-57940-9_28.

Snowdon DA, Leggat SG, Taylor NF (2017).

Does clinical supervision of healthcare professionals improve effectiveness of care and patient experience? A systematic review. BMC Health Services Research, 17(1): 9. doi: 10.1186/s12913-017-2739-5.

Umesawa M, Kobashi G (2016). Epidemiology of hypertensive disorders in pregnancy: prevalence, risk factors, predictors and prognosis. Hypertension Research, 4O(3): 214. doi: 10.1038/hr.2016.126

United States Agency for International Development (USAID) (2017). Be prepared for preeclampsia. http://www.endingeclampsia.org/world-pre- eclampsia-day/ - Diakses 15 Februari 2018.

Von Dadelszen P, Magee LA (2016). Preventing deaths due to the hypertensive disorders of pregnancy. Best Practice \& Research Clinical Obstetrics \& Gynaecology, 36: 83-90. doi: 10.1016/j.bpobgyn.2016.05.005.

Wang G, Oh IS, Courtright SH \& Colbert AE (2011). Transformational leadership and performance across criteria and levels: a meta-analytic review of 25 years of research. Group \& Organization Management, 36(2): 255. doi: 10.1177/1059601111401017.

World Health Organization (2015). Health workforce 2030: towards a global strategy on human resources for health. http://www.who.int/hrh/documents/15-295Strategy_Report-04_24_2015.pdf - Diakses 27 Februari 2018

(2014). A universal truth: no health without a workforce. http://www.who.int/workforcealliance/knowledge /resources/GHWA-a_universal_truth_report.pdf Diakses 20 November 2018

Yousaf A, Yang H, Sanders K (2015). Effects of intrinsic and extrinsic motivation on task and contextual performance of pakistani professionals. Journal of Managerial Psychology, 30(2): 133. doi:10.1108/jmp-09-2012-0277.

Zafar Q, Ali A, Hameed T, Ilyas T, Younas HI (2015). The influence of job stress on employees performance in Pakistan. American Journal of Social Science Research 1(4): 224. 